УДК 66.047

DOI

\title{
ІНТЕНСИФІКАЦЯ ВНУТРІШНЬОДИФУЗІЙНОГО МАСОПЕРЕНЕСЕННЯ ТА НАСИЧЕННЯ ТЕПЛОВОГО АГЕНТУ ВОЛОГОЮ ДЛЯ ПІДВИЩЕННЯ ЕНЕРГОЕФЕКТИВНОСТІ СУШІННЯ РОСЛИННОЇ БІОМАСИ
}

к.т.н. доц. Кіндзера Д.П., к.т.н. Госовський Р.Р., Д.т.н. проф. Атаманюк В.М. Національний університет «Львівська політехніка», м. Львів, Україна

\begin{abstract}
Анотація. В роботі обтрунтовано доиільність проведення наукових досліджень, спрямованих на інтенсифікацію внутрішньодифузійного масоперенесення прочесів сушіння рослинної біомаси з високими значеннями початкової вологості, зокрема стебел соняшника, а також динаміки насичення відпрацьованого теплового агенту вологою. Зважаючи на складність механізму фільтраційного сушіння, доказано необхідність визначення ефективного коефіиієнта дифузії, який сумарно враховує швидкість усіх видів дифузї̈ вологи, щзо мають місие під час реалізаџіï процесу $і$ дає змогу опису процесу масоперенесення згідно законів Фіка. Досліджено залежність ефективного коефіцієнта дифузії від температури та отримано залежності для розрахунку значень ефективного коефіцієнта дифузії вологи з подрібнених зовнішніх та внутрішніх тканин стебел соняшника в межах зміни температур теплового агенту 293 - $373 \mathrm{~K}$.

В роботі представлено результати експериментальних досліджень динаміки насичення відпраџьованого теплового агенту вологою у процесі фільтраџійного сушіння подрібнених стебел соняшника за різних початкових температур теплового агенту, щьо дає змогу рекомендувати оптимальні умови проведення прочесу.

Ключові слова: біомаса соняшника, біопаливо, внутрішньодифузійне масоперенесення, фільтраційне сушіння, ефективний коефіцієнт дифузії, зональний механізм, динаміка насичення теплового агенту.

\section{THE INTRADIFFUSION MASS TRANSFER INTENSIFICATION AND COMPLETE SATURATION OF THE THERMAL AGENT AS METHODS OF INCREASING THE ENERGY EFFICIENCY OF THE DRYING PROCESS}

PhD, assossiate Kindzera D.P., PhD Hosovskyi R.R., PhD, professor Atamanyuk V.M. Lviv Polytechnic National University, Lviv, Ukraine

\begin{abstract}
In Ukraine the most common types of biomass are waste raw materials from crop fields. Sunflower biomass, especially sunflower stems as lignocellulosic by-products, are of interest because they are not currently exploited but they can be successfully used as a raw material for solid bio-fuel production. Taking into account the high initial humidity of sunflower biomass as a raw material for the production of solid biofuel, which is about $60 \%$, and the energy intensity of the drying equipment, the cost of drying process is significant in technological line of fuel production.

The expediency of conducting the scientific research that aimed to intensify the intradiffusive mass transfer during the drying process of plant biomass with high initial humidity values as well as to increase the dynamics of the thermal agent saturation with moisture was justified in the article. Due to the complexity of the filtration drying mechanism, the necessity of the effective diffusion coefficient determination has been proved, which totally takes into account all kinds of moisture diffusion speeds and gives an opportunity to describe the process of mass transfer according to the Fick's laws. The temperature effect on the effective diffusion coefficient has been examined and graphs for effective diffusion coefficients determination have been obtained.

Equations which allow to calculate theoretically the effective diffusion coefficients for the grinded outer and inner sunflower stem tissues within the temperature range of $293-373{ }^{\circ} \mathrm{K}$ have been deduced. Experimental results of the thermal agent saturation with moisture at different temperature range during grinded sunflower stems drying which allows to recommend optimal process conditions in view of reducing energy costs also have been presented in the work

Keywords: sunflower biomass, solid biofuel, intradiffusive mass transfer, filtration drying, effective diffusion coefficient, zonal mechanism, dynamics of the thermal agent saturation.
\end{abstract}


Вступ. Високоврожайною та високорентабельною олійною культурою України $є$ соняшник, який дає змогу забезпечити потреби внутрішнього ринку насінням соняшнику - унікальною сировиною для отримання соняшникової олії, яка характеризується високою харчовою цінністю, зумовленою значним вмістом рослинних жирів, поліненасиченої лінолевої кислоти, вітамінів А, D, Е, К та інших, а також харчових та кормових видів білка з особливими біологічними та функціональними властивостями, високим вмістом біологічно активних речовин та широким набором макро-, мікро- та ультрамікроелементів [1]. Продукти на основі соняшникової переробки користуються сталим попитом на зовнішньому ринку.

За останні роки, в Україні спостерігається збільшення площ сільськогосподарських угідь, відведених під посіви соняшнику та зростання врожайності культури, спричиненого появою нових сортів. Однак, зважаючи на те, що соняшник є високо- та грубостебловою рослиною, він є також високоврожайним по «зеленій біомасі». Кількість відходів соняшнику по біомасі (стебла, листя, кошики, лузга), у післязбиральний період сягає, в середньому, 300-600 ц/га, тому проблема утилізації відходів переробки соняшника стоїть особливо гостро і вимагає розроблення раціональних способів утилізації «зеленої біомаси» 3 отриманням корисних продуктів [2].

Результати проведеного аналізу компонентного складу стебел соняшника та порівняння з вербою, яка вважається класичною енергетичною культурою, показують близькість значень показників компонентного складу стебел соняшника та енергетичної верби, що підтверджує можливість використання останніх в якості сировини для виробництва низькозольного, екологічнобезпечного твердого біопалива 3 достатньо високою теплотворною здатністю [3, 4].

Збільшення обсягів виробництва твердого біопалива 3 рослинної сировини, значну кількість 3 яких складають сільськогосподарські відходи $\epsilon$ актуальним завданням для більшості європейських держав. Переробка та утилізація сільськогосподарських відходів, з одержанням твердого біопалива, як цільового продукту, $є$ актуальними завданнями в умовах енергетичної кризи в Україні.

Частковий перехід на альтернативне паливо в державному та приватному секторах дасть змогу зменшити частку застосування традиційних джерел енергії, що сприяєтиме підвищенню енергоефективності економіки держави.

Узагальнені результати розробки та систематизації технологічних основ виготовлення твердого біопалива з рослинних відходів та композитів на їх основі представлені у роботах $[5,6]$, авторами яких вказується, що вологість подрібненої рослинної біомаси після процесу сушіння повинна становити 6-12\%. За вищої вологості біомаси відбувається «розривання» брикетів після реалізації процесу ущільнення, зумовлене внутрішнім тиском вологи, отже рекомендована вологість рослинної сировини у вказаних межах сприяє забезпеченню якісних характеристик отриманих брикетів.

Технологічні лінії для виробництва твердого біопалива оснащують стрічковими (прямо- та протитечійними; одноярусними та багатоярусними), барабанними сушарками, а також апаратами киплячого шару, однак вони є громіздкими, часто характеризуються низькою інтенсивністю перебігу тепло- і масообмінних процесів, потребують встановлення очисного обладнання [7-9].

Тому, зважаючи на високу початкову вологість біомаси соняшника, як сировинного матеріалу для виготовлення твердого біопалива, що становить близько $60 \%$, та енергоємність сушильного обладнання технологічних ліній, доля затрат на сушіння, в собівартості виготовлення палива, $є$ значною. Таким чином, зневоднення подрібненої біомаси соняшника $є$ одним з найважливіших технологічних етапів, який визначає питомі енергетичні затрати процесу виробництва твердого палива та якість готової продукції з вказаного типу сировини.

Аналіз проблематики та останніх досліджень. На даний час виникла потреба у дослідженнях, спрямованих на зниження енергоємності процесу сушіння рослинних матеріалів, що характеризуються високими значеннями початкової вологості. Під час реалізації процесів сушіння грубостеблової рослинної сировини, внутрішньодифузійні процеси перенесення вологи $є$ тривалими, оскільки практично вся волога $є$ внутрішньою і зосереджена в середині рослинних клітин та у міжклітинному просторі [10]. Дифузія молекул вологи з середини клітин через мікропори клітинної стінки $є$ найповільнішою стадією процесу, що лімітує загальну швидкість дифузійних процесів під час реалізації процесу сушіння, однак дещо інтенсифікується за збільшення температури процесу.

Встановлено, що фільтраційний метод сушіння, який полягає у профільтровуванні теплового агенту крізь канали, утворені між частинками дисперсного матеріалу, дає змогу інтенсифікувати процес сушіння подрібненої грубостеблової рослинної сировини, у порівнянні з іншими промисловими методами сушіння [11]. Інтенсифікація внутрішньодифузійних процесів перенесення вологи з одночасним зменшенням енергозатрат на реалізацію фільтраційного сушіння відбувається за рахунок внесення в стаціонарний шар подрібненої рослинної біомаси значної кількості теплоти за короткий період часу завдяки розвиненій поверхні тепло- та масообміну.

Фільтраційне сушіння також дає змогу використовувати тепловий агент з порівняно невисокою початковою температурою та досягати практично повного насичення відпрацьованого теплового агенту вологою

$$
\text { Наукові праці, Том 83, випуск } 1
$$


в кінці процесу, що сприяє збільшенню енергоощадності методу. Фільтраційне сушіння подрібненої біомаси відбувається згідно складного зонального механізму, який характеризується періодами повного та часткового насичення теплового агенту вологою, тому динаміка насичення відпрацьованого теплового агенту вологою має свої особливості, у порівнянні з іншими методами зневоднення [12]. Окрім цього, на динаміку насичення відпрацьованого теплового агенту вологою має вплив початкова температура, з якою агент подається у зону сушіння.

3 врахуванням вищесказаного, можна зробити висновок про те, що вивчення закономірностей внутрішньодифузійних процесів перенесення вологи та динаміки насичення відпрацьованого теплового агенту вологою у процесі фільтраційного сушіння подрібнених стебел соняшника за різних початкових температур теплового агенту є актуальними завданнями. Вирішення вказаних завдань дасть змогу розрахувати тривалість сушіння та встановити оптимальні параметри процесу з метою інтенсифікації та забезпечення енергоощадності. Отримані, в наслідок узагальнення результатів досліджень, розрахункові та графічні залежності матимуть практичне використання на стадії проектування сушарок фільтраційного типу для реалізації сушіння подрібненої біомаси соняшника.

Аналіз джерел літератури. Зважаючи на складність механізму фільтраційного сушіння, представленого автором роботи [12], процеси внутрішньодифузійного та зовнішньодифузійного перенесення вологи існують паралельно один до одного на протязі тривалого часу. Авторами робіт $[11,13]$, вказується на важливість визначення ефективного коефіцієнта дифузії, який сумарно враховує швидкість усіх видів дифузії вологи, що мають місце під час реалізації процесу фільтраційного сушіння і дає можливість опису процесу масоперенесення згідно законів Фіка.

Незначна кількість наукових праць містить відомості щодо методів розрахунку ефективного коефіцієнту дифузії для процесів сушіння матеріалів рослинного походження. В роботах [14 - 15] представлені аналітичні рішення рівняння Фіка для частин рослинного матеріалу у формі пластин та куль.

Отримані залежності є справедливими лише для частин досліджуваних матеріалів, що характеризуються особливістю внутрішньої структури з притаманною їм пористістю, розмірами, формою. Їх застосування для розрахунку коефіцієнта внутрішньої дифузії вологи під час фільтраційного сушіння подрібненої біомаси соняшника даватиме велику розбіжність між експериментальними і розрахованими даними.

Відомостей щодо дифузійного масоперенесення під час сушіння частин, утворених внаслідок подрібнення зовнішніх та внутрішніх тканин стебел соняшника, що становлять значну частину «зеленої біомаси» рослини, не знайдено. Тому, актуальним завданням є дослідження внутрішньодифузійних процесів, які відбуваються під час реалізації фільтраційного сушіння подрібнених стебел соняшника і спрямовані на визначення коефіцієнту ефективної внутрішньої дифузії вологи з середини частин матеріалу до їх поверхні.

Як вказується автором роботи [16], за реалізації процесу сушіння рослинної сировини конвективним методом, в зону сушіння подаються значні об'єми високотемпературного сушильного агента в межах температур $200-350^{\circ} \mathrm{C}$, що $є$ енергозатратним з точки зору організації процесу. Відповідно, відпрацьований тепловий агент викидається в атмосферу з температурою $70-150^{\circ} \mathrm{C}$, що вказує на значні втрати теплової енергії i, часто, є лише частково насичений парами вологи.

Реалізація сушіння рослинної сировини за використання фільтраційного методу має змогу використати тепловий агент з нижчим температурним потенціалом $40-120^{\circ} \mathrm{C}$, що зменшує енергозатратність процесу, на виході з шару матеріалу насиченість вологою є значно вищою, ніж за конвективного методу. Окрім цього, на динаміку насичення відпрацьованого теплового агенту вологою має вплив початкова температура, 3 якою агент подається у зону сушіння. Отже, важливим завданням є встановлення параметрів процесу, за яких досягається щонайповніше насичення теплового агенту вологою під час реалізації сушіння.

Метою роботи $є$ дослідження внутрішньодифузійних процесів перенесення вологи та динаміки насичення відпрацьованого теплового агенту вологою у процесі фільтраційного сушіння подрібнених стебел соняшника за різних початкових температур теплового агенту.

\section{Результати досліджень.}

Стебла соняшника складаються з кількох видів відмінних за своєю будовою тканин. Серцевину стебел формує паренхімна тканина (рис. 1a), утворена великими тонкостінними клітинами. Зовнішні тканини стебла формує епідерма, первинна кора (коленхіма та хлоренхіма), склеренхіма, первинна та вторинна флоеми та ксилема, міжпучковий камбій, утворені з товстостінних клітин невеликих розмірів (рис. 1б).

Внаслідок подрібнення внутрішньої тканини стебел утворилися частинки кулястої форми, а із зовнішніх тканин - частинки призматичної форми, які є дещо відмінними за своєю структурою, фізико-хімічним та біохімічним складом.

Середній початковий вологовміст подрібнених стебел соняшника становив $60 \%$ і обумовлений наявністю зв'язаної вологи, зосередженої в середині рослинних клітин та у міжклітинному просторі та незначної кількості вільної вологи на поверхні частин матеріалу. 


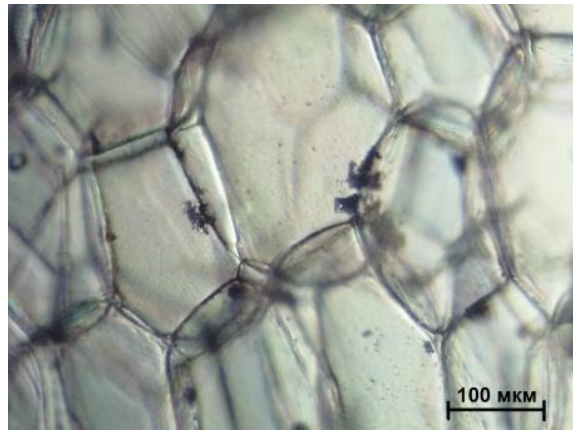

а) внутрішня тканина

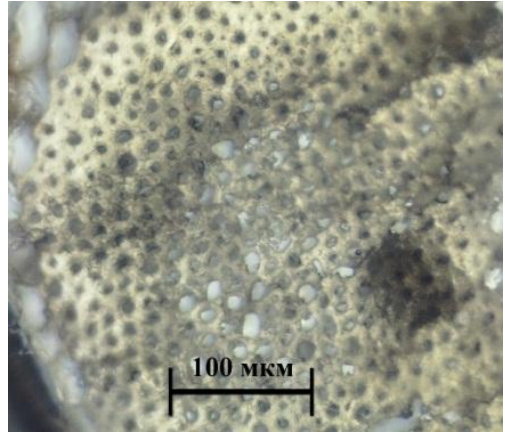

б) зовнішня тканина

Рис. 1 - Поперечні перерізи стебла соняшника

Попередньо, нами були досліджені кінетичні особливості фільтраційного сушіння подрібнених стебел соняшника за різних температур теплового агенту, що свідчили про наявність тривалого періоду внутрішньодифузійних процесів в частинках матеріалу під час реалізації фільтраційного сушіння [17]. Для дослідження внутрішньодифузійних процесів, контейнер з шаром матеріалу висотою $H=20 \cdot d_{\text {дас }}$ (де $d_{\text {дас }}-$ визначальний розмір частин кулястої форми) та $H=40 R$ (де $\mathrm{R}-$ визначальний розмір частинки призматичної форми) поміщали в установку фільтраційного сушіння та крізь стаціонарний шар вологого матеріалу профільтровували тепловий агент зі сталою витратою, нагрітий до температури 293, 313, 333, 353, 373 К. Температура теплового агенту контролювалася за допомогою електронного терморегулятора SESTOS D1S. Зміну маси матеріалу фіксували ваговим методом. Дослідження проводили до встановлення сталої маси матеріалу.

Метод визначення коефіцієнтів ефективної внутрішньої дифузії базувався на математичному розв'язку диференційних рівнянь внутрішньої дифузії (другого закону Фіка) з відповідними початковими та граничними умовами, а також $з$ прийнятими допущеннями: всі частинки подрібнених стебел соняшника мають призматичну (або кулясту) форму та однакові (співрозмірні) розміри; поверхня кожної частинки у шарі рівномірно омивається тепловим агентом; значення вологості на поверхні частинки відповідають значенням вологовмісту у тепловому агенті; початкова волога рівномірно розподілена по всьому об'єму кожної частинки. Визначені значення коефіцієнтів ефективної внутрішньої дифузії $D_{w}^{*}$ вологи з частинок утворених внаслідок подрібнення зовнішніх тканин стебел соняшника, визначені за різних температур теплового агенту наведені в таблиці 1 .

Таблицяя 1.

Значення коефіцієнтів ефективної внутрішньої дифузії за різних температур теплового агенту для частин утворених із зовнішніх тканин стебел соняшника

\begin{tabular}{|c|c|c|c|c|c|}
\hline$T_{v} K$ & 293 & 316 & 333 & 353 & 373 \\
\hline$D_{W}^{*} \times 10^{8}, \mathrm{M}^{2} / \mathrm{c}$ & 1,056 & 4,156 & 6,749 & 9,291 & 13,474 \\
\hline
\end{tabular}

Як видно з таблиці 1, значення коефіцієнтів ефективної внутрішньої дифузії зростають за збільшення температури теплового агенту. Явище пояснюється наступним чином: при збільшенні температури теплового агенту зростає температура всередині частинок та тиск насиченої пари над поверхнею рідини, внаслідок чого відбувається інтенсифікація дифузійних процесів.

За результатами таблиці 1 , побудована графічна залежність $D_{w}^{*}=\int(T)$ (рис. 2), яка $\epsilon$ зручною для практичного використання, оскільки дає змогу визначати значення коефіцієнтів ефективної внутрішньої дифузії для частинок утворених внаслідок подрібнення зовнішніх тканин стебел соняшника в межах зміни температур теплового агенту від 293 до 373 К.

Внаслідок апроксимації отриманих експериментальним шляхом значень коефіцієнтів ефективної внутрішньої дифузії лінійною функцією, отримали розрахункову залежність, яка дає змогу теоретично розрахувати значення вказаних коефіцієнтів в межах зміни температури $293 \leq t \leq 373 \mathrm{~K}$ :

$$
D_{W}^{*}=D_{W}^{29 a}+1,45 \cdot 10^{-9} \cdot(T-293)
$$

Визначені значення коефіцієнтів ефективної внутрішньої дифузії $D_{w}^{*}$ вологи з частинок подрібнених стебел соняшника кулястої форми, визначені за різних температур теплового агенту наведені в таблиці 2. 


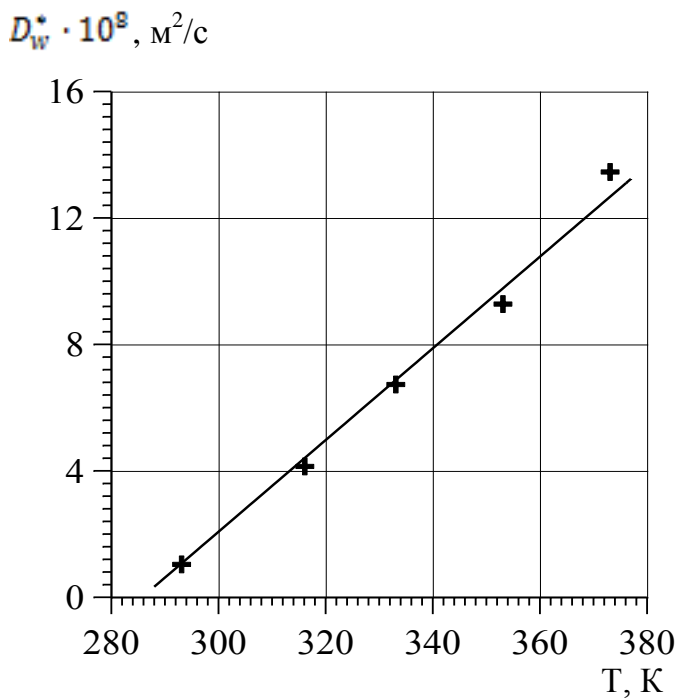

Рис. 2 - Залежність коефіціснтів ефективної внутрішньої дифузії $D_{W}^{*}$ від температури $T$ теплового агенту для частинок утворених внаслідок подрібнення зовнішніх тканин стебел соняшника

Таблиия 2.

Значення коефіціснтів ефективної внутрішньої дифузії за різних температур теплового агенту для частин утворених із внутрішніх тканин стебел соняшника

\begin{tabular}{|c|c|c|c|c|c|}
\hline$T_{v} K$ & 293 & 316 & 333 & 353 & 373 \\
\hline$D_{w}^{*} \times 10^{10}, \mathrm{~m}^{2} / \mathrm{c}$ & 0,396 & 3,211 & 5,641 & 8,872 & 11,103 \\
\hline
\end{tabular}

За результатами представленими в таблиці 2 побудована графічна залежність $D_{w}^{*}=f(T)$ (рис. 3).

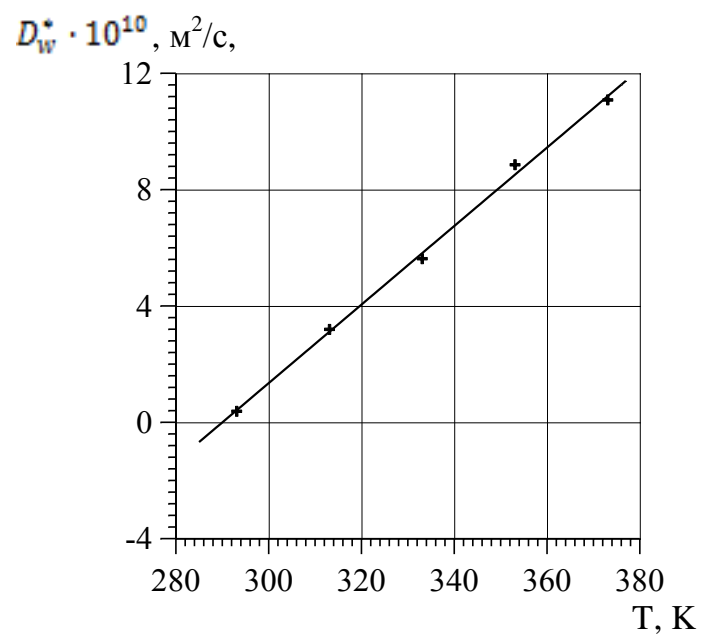

Рис. 3 - Залежність коефіціснтів ефективної внутрішньої дифузії $D_{W}^{*}$ від температури $T$ теплового агенту для частинок утворених внаслідок подрібнення внутрішніх тканин стебел соняшника

Отримана залежність для розрахунку коефіцієнтів ефективної внутрішньої дифузії $D_{w}^{*}$ для подрібнених внутрішніх тканин стебел соняшника в межах зміни температури теплового агенту $293 \leq t \leq 373$ К має вигляд:

$$
D_{w}^{*}=D_{w}^{29 a}+1,35 \cdot 10^{-11} \cdot(T-293)
$$

3 метою забезпечення високого насичення відпрацьованого теплового агенту під час реалізації фільтраційного сушіння подрібнених стебел соняшника, нами проведені дослідження зміни динаміки насичення останнього в часі за різних початкових температур теплового агента. За результатами експериментальних досліджень, побудовано графічні залежності зміни кількості вологи G, кг у тепловому агенті (рис. 4) та зміни вологовмісту $x, \kappa 2 \mathrm{H}_{2} \mathrm{O} / \kappa 2$ сух.пов. (рис. 5) в часі за різних початкових температур теплового агента.

Наукові праці, Том 83, випуск 1

Scientific Works, Volume 83, Issue 1 
$G \cdot 10^{2}, \kappa \Gamma \mathrm{H}_{2} \mathrm{O}$

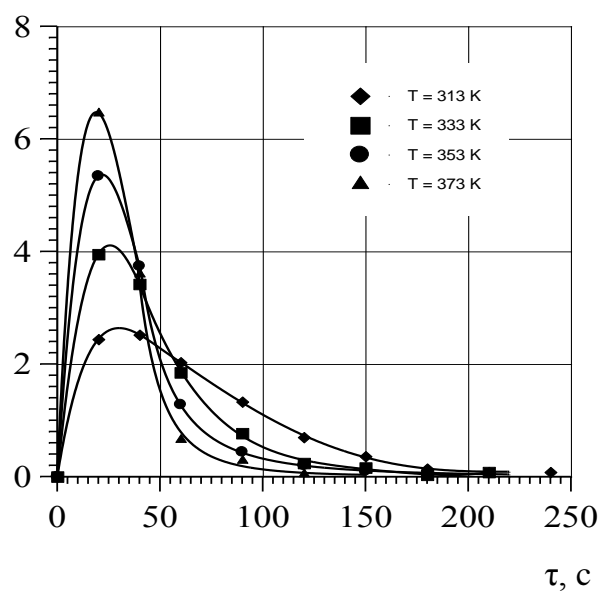

Рис. 4 - Динаміки насичення відпрацьованого теплового агента: залежність зміни маси вологи у тепловому агенті від часу за різних початкових температур $x$, кг $\mathrm{H}_{2} \mathrm{O} /$ кг сух.пов.

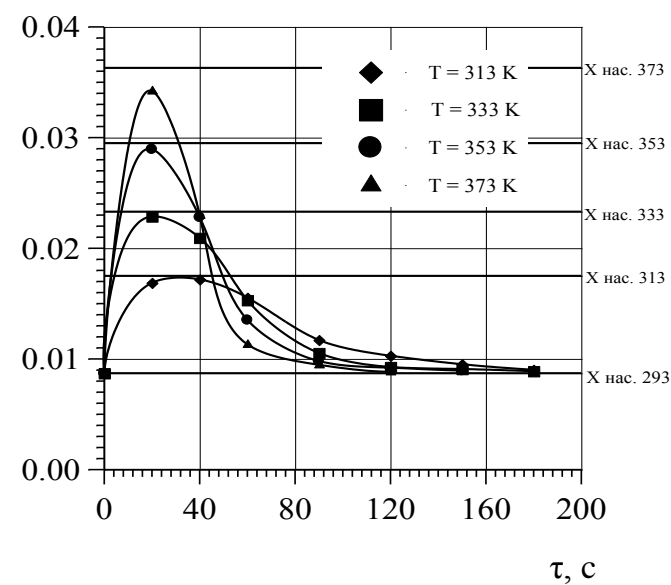

Рис. 5 - Динаміки насичення відпрацьованого теплового агента: зміна вологовмісту теплового агенту в часу за різних початкових температур

3 представлених графічних залежностей видно, що у загальному випадку криві характеризуються двома ділянками, які відповідають періодам повного та часткового насичення теплового агента вологою. Від початку процесу сушіння до досягнення фронтом масообміну перфорованої перегородки кількість вологи, що переходить у відпрацьований тепловий агент та, відповідно, вологовміст останнього зростають і у момент досягнення фронтом масообміну перфорованої перегородки досягають максимальних значень. Насичення теплового агенту максимальною кількістю вологи за даних умов характеризується піками на відповідних кривих.

Після досягнення фронтом масообміну перфорованої перегородки, починається період часткового насичення теплового агенту вологою, що характеризується поступовим зменшенням кількості вологи, що переходить у тепловий агент та, відповідно, вологовмісту останнього аж до моменту припинення сушіння.

Збільшення початкової температури теплового агенту від 313 до 373К приводить до зростання маси вологи, що переходить у відпрацьований тепловий агент в момент його повного насичення від $2,6 \cdot 10^{-3}$ до $6,5 \cdot 10^{-3}$ кг $\mathrm{H}_{2} \mathrm{O}$ та вологовмісту останнього, відповідно, від 0,0175 до 0,0365кг $\mathrm{H}_{2} \mathrm{O} /$ кг сух.пов. у період повного його насичення вологою (рис. 4,5 ). Це пояснюється інтенсифікацією процесу сушіння за рахунок зростання швидкостей дифузійного переміщення вологи в матеріалі, а, отже, і збільшенням кількості винесеної вологи з зони сушіння. Вплив початкової температури теплового агенту на вміст вологи у відпрацьованому тепловому агенті та його вологовміст у момент повного насичення представлено у таблиці 3.

Таблиия 3

Вплив початкової температури теплового агенту на вміст вологи у відпрацьованому тепловому агенті та його вологовміст у момент повного насичення

\begin{tabular}{|c|c|c|c|c|}
\hline Початкова температура, $\mathrm{K}$ & 313 & 333 & 353 & 373 \\
\hline Маса вологи, $G \cdot 10^{\text {a }}, \kappa 2 \mathrm{H}_{2} \mathrm{O}$ & 2,6 & 4,1 & 5,4 & 6,5 \\
\hline Вологовміст, х, кг $\mathrm{H}_{2} \mathrm{O} /$ кг сух.пов & 0,0175 & 0,0234 & 0,0298 & 0,0365 \\
\hline
\end{tabular}

\section{Висновки.}

1. Визначено значення коефіцієнтів ефективної внутрішньої дифузії вологи з подрібнених зовнішніх та внутрішніх тканин стебел соняшника за різних температур теплового агенту під час фільтраційного сушіння (таблиці 1 та 2).

2. Отримані графічні залежності $D_{w}^{*}=\int(T)$ (рис. 2, 3), які є зручними для практичного використання, оскільки дають змогу визначати значення коефіцієнтів ефективної внутрішньої дифузї̈ для частинок утворених внаслідок подрібнення зовнішніх та внутрішніх тканин стебел соняшника в межах зміни температур теплового агенту від 293 до 373 К. 
3. Отримані розрахункові залежності, які дають змогу теоретично розрахувати значення коефіцієнтів ефективної внутрішньої дифузії для подрібнених зовнішніх тканин стебел соняшника (1) та внутрішніх тканин стебел соняшника (2) в межах зміни температури теплового агенту $293 \leq t \leq 373 \mathrm{~K}$.

4. Досліджено динаміку насичення відпрацьованого теплового агенту вологою у процесі фільтраційного сушіння подрібнених стебел соняшника за різних початкових температур теплового агенту, що дає змогу рекомендувати оптимальні умови проведення процесу.

\section{References}

1. Zaitsev, O.M. (2002) Vykorystannia yakisnoho nasinnia — naishvydshyi shliakh do pidvyshchennia efektyvnosti silskohospodarskoho vyrobnytstva. Propozytsiia. 5. 48 .

2. Lakiza, O.V., Rudnieva, L.L., Chursinov, Yu.O., Demidov, I.M. (2011) Zastosuvannia vidkhodiv pererobky nasinnia soniashnyku. Visnyk Dnipropetrovskoho derzhavnoho ahrarnoho universytetu (2), 14-16.

3. Kindzera, D.P. (2017) Zmenshennia enerhozatrat tekhnolohichnoi linii vyrobnytstva tverdoho palyva $\mathrm{Z}$ biomasy soniashnyka. Seminar. Stalyi rozvytok - pohliad u maibutnie. Zbirnyk materialiv. Lviv, 15 veresnia 2017. 38 .

4. Kindzera, D.P., Atamaniuk, V.M., Hosovskyi, R.R. (2015) Vyznachennia optymalnykh parametriv sushinnia podribnenykh stebel soniashnyka dlia vyrobnytstva palyvnykh bryketiv. Naukovi pratsi Odeskoi natsionalnoi akademii kharchovykh tekhnolohii, 47(2),194-198.

5. Klymenko, V. V., Kravchenko, V. I., Bokov, V. M., Hutsul, V. I. (2017) Tekhnolohichni osnovy vyhotovlennia biopalyva $\mathrm{z}$ roslynnykh vidkhodiv ta yikh kompozytiv: Monohrafiia. Za red. V.V. Klymenka Kropyvnytskyi: PP «Ekskliuzyv-System», 162.

6. Haidenko, O. (2014) Tverde biopalyvo: tekhnolohichni vymohy, vlastyvosti komponentiv ta tekhnolohiia vyrobnytstva. Hazeta "Ahrobiznes sohodni"19(290), 22 zhovtnia 2014, TOV "Pres-media" 2014. Retrieved from: http://www.agrobusiness.com.ua/ideii-i-trendy/2424-tverde-biopalyvo-hnologichni-vymogyvlastyvostikomponenttiv-ta-tekhnologiia-vyrobnytstva.html.

7. Troshin, A.G., Moiseev, V.F., Telnov, I.A., Zavinskiy, S.I., Troshin, A.G. (2010) Razvitie protsessov i oborudovaniya dlya proizvodstva toplivnyih briketov iz biomassyi. Vostochno-Evropeyskiy zhurnal peredovyih tehnologiy. 3/8 (45), 36-41.

8. Bilei, P.V., Prystavskyi, B.I. (2012) Analiz efektyvnosti konvektyvnoho sushinnia derevyny. Naukovyi visnyk NLTU Ukrainy. 22(10), 116-119.

9. Snezhkin, Yu.F., Sorokovaya, N.N. (2016) Matematicheskoe modelirovanie dinamiki sushki kolloidnyih kapillyarno-poristyih tel v usloviyah kipyaschego sloya. Odeska natsIonalna akademIya harchovih tehnologIy. NaukovI pratsI, 80( 1), 86-91.

10 Hosovskyi, R.R., Kindzera, D.P., Atamaniuk, V.M. (2017) Vnutrishnodyfuziine masoperenesennia pid chas filtratsiinoho sushinnia perankhimnoi tkanyny stebel soniashnyka. Naukovyi visnyk Natsionalnoho lisotekhnichnoho universytetu, 27(6), 112-116.

11. Hosovskyi, R., Kindzera, D., Atamanyuk, V. (2016) Diffusive mass transfer during drying of grinder sunflower stalks. Chemistry \& Chemical Technology. 10(4), 194-198.

12. Atamaniuk, V. M., Humnytskyi, Ya. M. (2013) Naukovi osnovy filtratsiinoho sushinnia dyspersnykh materialiv. Lviv: Vydavnytstvo Lvivskoi politekhniky. 276.

13 Atamaniuk, V.M., Huzova, I.O., Hnativ, Z.Ia., Patrii, N.O. (2017) Doslidzhennia dyfuzii molekul sakharozy v chastynkakh plodu harbuza u vyrobnytstvi tsukativ. Khimichna tekhnolohiia ta inzheneriia. Mizhnarodna naukovo-praktychna konferentsiia. Zbirnyk tez dopovidei. Ukraina, Lviv, 107 - 108.....

14. Mirtes Aparecida da Conceição Silva, Zaqueu Ernesto da Silva, Viviana Cocco Mariani, Sébastien Darche.(2012) Mass transfer during the osmotic dehydration of West Indian cherry. LWT - Food Science and Technology, 246-252.

15. Raquel, P.F., Guiné and Maria João Barroca. (2013) Estimation of the diffusivities and mass transfer coefficients for the drying of D. Joaquina pears. Proceedings of the World Congress on Engineering 2,WCE 2013, July 3 - 5, 2013, London, U.K.

16. Shandyba, N. O., Yukhymenko, M. P. (2011) Strukturnyi analiz vtrat v tekhnolohichnykh protsesakh pererobky silskohospodarskoi produktsii. Problemy enerhoefektyvnosti ta yakosti v protsesakh sushinnia kharchovoi syrovyny : zbirnyk tez dopovidei Vseukrainskoi naukovo-praktychnoi konferentsii. Kharkiv, 101-102.

17. Kindzera, D.P., Atamaniuk, V.M., Hosovskyi, R.R. (2016) Kinetyka filtratsiinoho sushinnia podribnenykh stebel soniashnyka. Naukovi pratsi. Odeska natsionalna akademiia kharchovykh tekhnolohii, 80(1), 32 - 37.

Отримано в редакцію 11.04.2019

Прийнято до друку 18.06.2019
Received 11.04.2019

Approved 18.06.2019 